\title{
A COMPARATIVE ANALYSIS OF THE HUMAN MIND IN TWO FILMS: PI AND A BEAUTIFUL MIND
}

Mehmet Aziz Göksel ${ }^{1}$

MALTEPE ÜNIVERSITESİ, Mimarlık Fakültesi
Original scientific paper

UDC: $791.235: 159.9$

791.3:81:22

Received: 13.06.2014.

Accepted: 16.08.2014.

\begin{abstract}
In this study, a semiotic reading and the comparison of the films Pi and Beautiful Mind is made from various aspects. The study makes use of semiotics and attempts to analyze and match mutually, the verbal signifiers and their signifieds, contained in the films. Some common attributes of these two films and the contemporary character of the sign (signification) types, determines the field of interest of the study. The fact that the "human mind" takes place as a major theme in both works, paves the way for the selection of the research material. The findings accessed through the research, shed light on the interpretation of the social, scientific and cultural events of the so-called informtion age -those can be qualified as a revolution- in the last decades.
\end{abstract}

Keywords: Semiotics, mathematics, human mind, modernity, psychosis, mystisim, obscurantism.

\section{INTRODUCTION}

This study is a comparative analysis of two films. The first of these is Pi, written and directed by Darren Aronofsky and shot in 1997 while the second is A Beautiful Mind, made by Ron Howard in 2001. The common characteristics and signifiers used, being specific to this age, have set the area of interest of the study. The reason why I have focused my research on these two films is the hypothesis that the film sector is focusing on the development of the "human mind today", using "signifiers specific to the modern age" to conveny messages.

"Umberto Eco said that the act of producing a work of art had various aspects, such as the manufacture of signs, the creation of a universe of expression in which these sgins would be functional and the development of communication skills that would make the provided codes understandable" (Caesar, 1999). In recent years, the manufacture and presentation of these codes has taken precedence of verbal and written communication, creating a "visual culture" that has been widely debated, while the film sector, as the most widespread and effective means of mass communication has played the lead role, bringing a certain rational validity to the desire to create such works.

Especially with the period of rapid change starting after World War 2, the "human mind" and its most important product, "civilization", have been in affected by a trend seeking to redefine all dimensions of their boundaries and area of activity. The dizzying increase in information is only matched by the speed of which the information is being accessed by the masses. Today, the computer, which is a driving force in the process described above, is recognised with an identity that is in competition with the human mind. This situation, hinting at the birth of a new age, is reshaping the role of and expectations from civilization at its peak. The man of today is questioning his faith in modern civilzation. Under the influence of anxieties towards the rational mind and civilization, its most significant product, humankind tends to instrumentalise all significant developments in some form.

\footnotetext{
${ }^{1}$ Correspodence to:

Mehmet Aziz GÖKSEL, MALTEPE ÜNIVERSíTESİ, Mimarlık Fakültesi, Gemi ve Yat Tasarımı Bölümü Kurucu Başkanı Hamiyet Yüceses S. 54/14 34740 Suadiye, İstanbul-TÜRKIYYE

Phone: +90 2163734882 Gsm: +90 5322342814

E-mail: mehmetazizgoksel@gmail.com
} 
In some cases, frightening events stemming from the untethered meanderings of the mind damages the consciousness of the lead actors in the civilization manufacturing mechanisms and geniouses on the balancing on the verge of psychosis cause the downfall of spiritual structures. The lead characters in both films are people of this type. This study, designed in the light of these observations, aims to present important data regarding the main factors in the selection of signifiers in a specific period as well as the factors specific to the culture of the period.

\section{METHODOLOGY}

As the examination of intellectual products in the social sciences mainly rests on the utilisation of abstract concepts such as meaning and signifiers, the techniques used usually do not include experimental methods as the subject matter does not usually allow for experimentation. The methodologies used in linguistic and semiotic research are generally descriptive. Research in these fields will general rest on observational techniques. In this study, the phenomenon that are reported or observed by the researcher are mainly assumptions that are presented to be considered or tested by the reader. For this reason, in various fields that lean on comments, such as literature, drama and film critique, the points presented by critics may be different or even contradictory. The judge in such cases where contradictory viewpoints are expressed in the reader. In this study, as two films (two paradigms) are being compared, it has not been possible to use a significantly large population of people who have either watched both films or are willing to watch them, as experimental subjects. The data presented here, "Coalistions between the signifier and signified" are the observations of the researcher. These signifiers are both descriptive/denotational and through assonance, implicataive/connotational at the same time (Barthes: Rethoric of the Image; 1966) ${ }^{2 *}$ ).

\footnotetext{
2 (*) The French and Anglosaxon schools of semiotics describe a number of concepts and types of signifiers. Semiotic studies use different perception and conceptual concepts, such as index, image, icon, mythic signifiers, literal signifiers, aural signifiers, pictographic signifiers, slippage, skidding and many others in order to explain the connections of meaning between signifiers and signified elements. In this sutdy, we will not use a taxonomic approach that classifies the type of signifiers identified (index, aural, textual, linguitic etc.), focusing only on the relationship between the signifier and the signified.
}

Based on an effort to comment upon these signifiers in a realistic manner, some techniques have been put into practise, as summarised below:

1.The visual, aural and textual signifiers within the material have been identified and recorded. The messages implied by each signifier have also been recorded, reviewed ${ }^{(*)}$ and ranked.

2.The signifiers appearing in Pi and A Beautiful Mind have been listed (in the form of two separate lists) according to the "signifier-signified coalitions" (Rifat, 2000).

3. The common signifiers in both films have been matched and explained in the form of "joint findings".

The significations in this list are mainly aimed at subconscious associations and may be increased or decreased according to the size and variation of the audience. Furthermore, in heterogeneous groups the idiolects and lexicons of the individuals (signifier jargon) will not be identical, meaning that some significations will be perceived differently. In any case, there is no doubt that the lists presented offer a descriptive picture of the language used in the films.

\section{THE HUMAN MIND AS AN OBJECT AND A SUBJECT}

As the research is based on the signification of the human mind in the film sector, it is fitting that this concept is examined from a subjective and objective viewpoint. Any viewpoint on the human mind will either percieve the concept as an object to be examined or will base the examination stemming from the reseacher's own consciousness and perceive the concept as a subject. The first approach may be defined as the "objective method" while the latter as the "subjective approach (Cevizci, 2000).

"The subjective approach by humans towards themselves and events is older than the objective approach. The most primitive example is seen in Animism, the oldest human belief system" (Bolay, 1997). Primitive humans transferred willpower, an activity of the human mind, to objects in the world around them and believed that these objects had will or a kind or consciousness. According to this approach towards theological systems, natural phenomena were a product of the subjects that initiated them.

$\left.{ }^{\star}\right)$ Exegesis: Plainly, commenting on the content. This approach is based on the conceptualisation of the whole starting from the content and proceeding with secondary meanings. 
We know that there are philosophical systems that maintain that the objective approach is not as naive as it seems, such as phenomenology, existentialism and philosophical anthropology.

"Humans have the capacity to sense, percieve, deduce, describe and comment on the other, or other beings that sit outside of the field of existence described as the self. In sum, this field of existence is an objective and concrete are populated by objects that are not included in the concept of self. Humans are able to gather information regarding experiences that are owned within the area of self consciousness -meaning patterns or concepts of of perception that constitute the content of consciousness- either directly or through a system of signifiers. Furthermore, humans may reach information regarding non subjective entities through subjective information acquisition, meaning the senses and rational processes that process and organize data acquired from sensory perception. Apart from information regarding other objects and the subjective entities that are others, information is percieved regarding the consciousness area of others (others thoughts, the experiences of the self of the other). It is not impossible to draw conclusions regarding the minds and mental activities of others by examining the results of these activities. Especially in the 20th century, objective measures such as intelligence and aptitude tests have been developed to examine the capabilities of the human mind" (Krech, Crutchfield, William, 1974; Morgan, 1991). "Many of these are mathematical equations” (Işık, 2001; Cüceloğlu, 1991).

\section{MENTAL ILLNESS}

A significant and striking theme that is observed over nearly all aspects of the two films examined is mental illness. "Psychosis is the name we give to significant psychological disorders. In general, psychosis required clinical treatment. Psychoses can be categorised under two main headings; functional and organiz psychosis (Cüceloğlu, 1991).

"Psychoses are personality disorders in which the individual is in conflict with her surroundings and are more serious than neurotic disorders. Neurotics are aware that they are ill; psychotic patients' link to reality has been severed and psychotics dispute that they are ill" (Iş1k, 2001.)

"Delusions: False beliefs specific to patients that are incompatible with the reality of the age and society the person is living in, and that cannot be changed through the presentation of logical evidence" (Iş1k, 1997).

"Hallucinations: Defects in perception. Hallucinations are phenomena of perception occurring without any external stimuli (or objects). Hallucinations are non existant sounds heard, visions seen and odours smelt without any emotional stimulations" (Iş1k, 1999; Cüceloğlu, 1991).

The most significant functional psychoses are Schizophrenia $^{3(*)}$ and related psychoses, paranoid and affective psychoses (melancholia, mania etc.). We can also refer to rarely observed acute psychoses that cannot be classified under any category and psychotic episodes observed in personality disorders.

"There are a number of views on the factors causing psychosis. Although the socio-cultural events and anxiety the individual is subjected to from a young age are thought to be responsible for psychosis, the main factor is the individual's genetic code" (Arslanoğlu, Akman, 2002).

$3^{3(*)}$ Schizophrenia, meaning "split mind" in Greek, is the most serious among mental disorders. Schizophrenia presents with divided though processes, inconsistency, emotional problems and autism. The illness begins in the twenties and is observed in 1 in every 2000 people. (Işık, 2001; Işık, 1997; Arslanoğlu, Akman; 2002). 


\section{SIGNIFIERS IN PI}

\section{Table 1}

\begin{tabular}{lll}
\hline \multicolumn{1}{c}{ Signified by } & \multicolumn{1}{c}{ Significations } \\
\hline Maximilian Cohen (Protagonist). & $\begin{array}{l}\text { Loneliness, isolation, fixation on the abstract, } \\
\text { mathematical world view, drive to research }\end{array}$ \\
& $\begin{array}{l}\text { Furthermore: Living in China Town, New York among the } \\
\text { diaspora signifies his personality. }\end{array}$ \\
& $\begin{array}{l}\text { Max's genetic heritage and elite status (Levi and Cohen } \\
\text { were the sons of Jacob). }\end{array}$ \\
The Cohen surname & $\begin{array}{l}\text { Diaspora, diaspora culture, postmodern situation, } \\
\text { Tai - Chi - Chuan, Chinese and English } \\
\text { signboard, the Indian girl Devi, stockbroker } \\
\text { Marcy Dawson, the lonely man talking to }\end{array}$
\end{tabular}
himself in the text.

Small and dirty apartment

If the use of such an apartment does not signify the poverty or economic situation of the character, it shows his passion towards his pursuits to the degree of mania and his lack of interest to anything else.

Computer

Mathematics

1) Intelligence, 2) knowledge and science, 3) Brain, 4) Logic and scientific method, 5) mathematics.

- In Cohen's language, the iron law of nature (clichés). Numbers are the key to solving the mystery of the universe.

Universal coefficients, ratios, constants

- In Cohen's language, the organized unity of the universe, the universality, existence and oneness of laws. The compliance of the mind to nature. The predictive character of science. The assumption of the unity of science

The data tapes seen in the apartment and on the street Information and communication age. Speed of action and information.

The number Pi

One of the basic constants of nature. The unknown resisting challenge. The call of the unknown. The attractiveness of irrational vision, insolvability and infinity.

Migraine

1) Half head ache, 2) the illness Cohen has suffered from since age 6,3) Symbolically, the punishment for being curious and not listening to elders. The monologue "mother told me not to look at the sun", 4) Iron law of nature, feedback protecting balance in the face of interventions towards the natural order, 5) Flashing lights, intense light (e.g. reading newspapers on the beach triggers migraine).

Epilepsy $^{1{ }^{(*)}}$

1) A great obstacle (Cohen has seizures more frequently when nearing success, preventing him from reaching a conclusion), 2) Severe seizures present with full loss of consciousness. Partial seizures appear with hallucinations, automatic behaviour or a dream state, ending in major seizures.

${ }^{(*)}$ The protagonist in $\mathrm{Pi}$, Cohen, is a TLE patient. The aura starting with hamd cramps leads to migraine headaches, nausea, visual hallucinations, noseblooks and the continued exposition of the temporal part of the head.

TLE (Temporal Lobe Epilepsy) is the most complex and difficult to treat type of epilepsy. TLE starts usually in the 20 's. Seziures are accompanied by repeated cramps in the hands and fingers. Most patients present a variety of auras. These may be sounds, smells, tastes, stomach and intestinal complaints, migraines or hallucinations. Seizures are protracted and take a long time to pass. The patient's blood pressure may rise and nosebleeds may occcur. Epileptic patients have psychological problems. The mental activities of the patients are blocked by seizures, however epileptic persons are completely normal outside of the seizures. They are not psychotic (crazy); their logical, memory, comprehension, perception and sensory functions are intact (Işık, 1999). 
Blank!

Light

Medication

Coffee

Marcy Dawson

Lenny Meyer

Kabal, Kabalism, Kabalists

Mystic approach, gemantria (Kabalist number concept), numerology

Secientific approach (anti mysticism. Scientific laws and inventions)

Sol Robeson

The first integrated circuit given by Dawson

Cohen's landlady

Vaccine gun

Gemantria (mystic numbers theory)

Tefelin

The golden spiral, golden ratio, Fibonacci series 216 digit number

Icarus (Sol's black coloured fish)

Archimedes (White fish in the tank)

Gemantria diskette

The second integrated circuit sent by Dawson

Bloody hand (the blood dripping from Cohen's hand).

Pulsating brain
1) In the film, severe seizures, referred to as "grand mal" and ending in the loss of consciousness are represented with this visual sign, 2) Mysterious comment: Illumination. Some who believe that they are holy reach superhuman knowledge. The film represents this level of consciousness as hallucinations after the "blank".

1) The fate of Icarus in mythology: Ikarus melted when he strayed too close to the sun, 2) Cohen's failure to heed the warning not to look at the sun, 3) The punishment to attempt to see and understand too much, obscurantism.

The weapon of modernity against a natural phenomenon (illness). Passion to conquer nature.

A drug that sometimes prevents migraines. The effort to resist.

The rising new diasporic, disphoric and postmodern values. In a WASP dominated society a black women who is also ugly is able to rise to the top from the very bottom. Aggressive and ambitious. The lust for money leads to unethical behaviour.

A premodern type. Mysterious, warm, lively and a little intrusive. Symbolises the aims of the cult.

Esoterism, mysticism, ethnocentrism, orthodoxy, even fundamentalism, fanatism, premodernist protests.

Mysticism, hermetism and other anti scientific attitudes, obscurantism.

Observationism, experimentalism, rationalism (from Max's monologues).

A burnt out and pessimistic mathematician who worked for the same cause as Cohen in his youth,

1) A father figure in conflict with the new generation, 2) Cohen's alterego.

1) Capitalism taking scientific research captive, 2) Technological development (the universe outside of living beings).

A fat and aggressive woman. A spy set on Cohen by Marcy Dawson and the Wall Street Mafia (probably).

Gun

Mysticism

Ethnocentrism, even racism, esoterism, brotherhood bonds.

Mathematics of nature.

1) Mysticism of nature, 2) Fate written by the creator.

This signifier leads us to the story of Icarus in Greek mythology. Icarus tries to reach the gods by flying but his waxen wings melted in the sun: obscurantism.

"Comfort is necessary to think. Patience is beneficial".

The fact that the realities of numerology where known to the ancients. The principle of nature complying with reason.

The latest product of technological evolution. The gift of modernism. The idea that science supports technology and technology supports science.

1) Autoscopic hallucination (Alter-Ego). 2) Drive or fear of self punishment.

Evolution from unloving matter to human consciousness and willpower. The brain would not live when separated from the human being. Remniscent of when Cohen asks "does the computer have a brain?" to which Sol Robeson replies "sometimes, in a way, yes". 
Tension

Rabbi Cohen

Nagem David

Ants

Death of the Computer

The growing, developing computer

The game of Go

Lust for 1) money, 2) power, 3) scientific curiosity

The stock exchange

Hallucination, mania and pathological thought

Human brain

Mental (brain) illness

Bugs

Bloody brain

Being a mathematician

Headaches

Stroboscope (strobe visual effect)

Paranoid syndrome and panic attack Drill (in this film)

Secret (both meanings of the word)

The passenger on the subway
The fight scenes, abduction at gunpoint at the end of the film openly shows the conflict between the protagonist and antagonists.

Lust for power, Zionism, racism, bigotry...

The promised kingdom, King David's arms, symbol of Zionism.

The agent of fate and its mission. According to what Sol says about computer consciousness, the function of each part of the universe in respect to the whole. Ants cause circuits to fail, for secrets to be left unfinished, an agent charged with preventing the secret from getting out. Ants in the brain can be considered as factors attacking thought processes. Euclide was broken by a ant. The bugs are shown full screen. This shows that the signifier is especially important.

1) According to what Sol says about the consciousness of the computer, the machine does a complete memory read before crashing, 2) The death of modernity.

1) The question of sentience, 2) The passion for development and competence inherited by the Enlightenment from the Rennaisance.

1) Singularity (uniqueness of snowflakes), 2) Unity in variety (chaos theory), 3) Teleology (means to an end), 4) Conlifct, competition and struggle (war games, war diplomacy, politics, economics, game theory, natural dialectics).

The motivation for the fight for life and evolution.

1) "Everything affects one another" (Butterfly effect), 2) Competition (race against the clock and against fate).

False judgement, reasoning disorder that confuses right and wrong, an indicator of mystery syndrome.

1) The mind, intelligence, 2) human beings, 3) the image of the brain is symbolised in Maximilian Cohen's personality. 1) Pure rationality and its disorder, 2) the character in the film, being Cohen.

1) In the basin and on the floor, a symbol of neglect in the house, 2) in the brain, the attack of nature on Cohen's brain and mind (agents of fate).

1) Frightening expectation, 2) Punishment for Cohen's curiosity as the sufferer in this film.

The critical position of the human mind. The thin line between glory and downfall, genious and insanity.

1) Punishment, 2) The iron law of nature (the obstacle in front of the loss of balance)

1) Subliminal visualisation, 2) The stimuali seen in epileptic seizures and migraine, 3 ) a form of diagnosis for epilepsy.

Symptoms of mystery syndrome

1) Guns, associated with suicide, 2) Lobotomy (see introduction), 3) an instrument of treatment, 4) Death of the mind: Obscurantism.

1) The unknown, a secret that is not known 2) an unknowable and transcendent truth.

Although the subway is a form of mass transit, we only see one passenger. This one passenger signfiers all passengers or the society itself (loneliness in a crowd, alienation)." 
The neighbour Devi. She appears to be Indian and is trying to become close to Max, but Max has a fixation on science and has no other passions (even if this passion is related to a sex object).

Coney Island

Locks

Nosebleeds

Shaking thumbs
Exotism, love, human compassion.

Symbolises peace and quiet. The image is quite stark when comparet to the fast pace of the film. The music is light and peaceful. The ocean here is the unknowability of eternity...

Paranoia, fear, isolation, loneliness.

Increase of blood pressure during epileptic seizures.

1) Aura, the indicator of an approaching severe seizure, 2) a symptom of partial epilepsy in the absence of a serious seizure.

\section{SIGNIFIERS IN A BEAUTIFUL MIND}

\section{Table 2}

\begin{tabular}{ll}
\hline Signified by & \multicolumn{1}{c}{ Significations } \\
\hline Mathematician archetype & Symbolised in the extreme and unconforming personality of \\
& young Nash, traits such as high intelligence, vanity, harsh \\
competition and underestimating rivals, emphasising both in & the film and in Nash's biography, that mathematicians are not \\
normal people (these people consider themselves to be & superior as they see what others cannot).
\end{tabular}

Akward social relationships, rude behaviours, Schizophrenic character traits. behavioural issues such as insulting while laughing.

The blonde girl in the student's club 1) a crude offer made to the girl who was willing to interact, 2) laughing after being slapped

The game of Go

Writing formulae on glass instead of paper

Belittling lessons and students

1) Throwing the table out of the window 2) throwing and tearing papers when the thesis proposal is rejected

Talking to oneself

Discovery of the Nash balance theory ${ }^{1 *}$ spontaneously at the club

Hesitation in selecting a thesis topic

1) Problems in forming relationships, isolation, 2) social incompatibility.

This game signifies not only wargames, but all types of competitive relationships, war, diplomacy, economic and dialectic situations.

Doing what you want, not caring about the world or norms (indifference is a character trait seen in schizophrenia).

Paranoid character trait (calling students "idiots who love to memorise").

Lack of control over drives is an indication of psychosis or mental illness.

1) At first, introversion, isolation from society, 2) Hearing voices after the hallucinations start (a symptom of severe mental illness).

This important signifier shows that despite emotional disorders, the cognitive faculties are still present and take a long time to be eradicated.

This attitude, frowned upon by the advisor, may be explained with "blockage", a preliminary symptom of schizophrenia.

${ }^{1(*)}$ The thesis that John Nash had proposed in 1947 was to be an extension of the Game Theory developed by Morgenstern, a professor at Princeton. Morgenstern believed that the idea was not worthy of research. In any case, the proposal was accepted and published, after which it was cited by a number of scholars. After a long break, the article and its commentary was revived not by mathematicians, but in the field of economics. Nash's views became very imortant during the last phase of his sickness and the Nobel Prize for Economics, that was recently inaugurated, was awarded to John Nash after a gap of 47 years. The strategy aiming to take into account all of the choices of the opponent in order to win is known as "Nash's Point of Balance" (Stahl). 
Adam Smith

Blonde girl exposure

Pentagon

Beer party in the garden thrown in John's honour after his dissertation proposal has been accepted

Codes (cyphers)

Code breaking

Fear

MIT (Massachussettes Institute of Technology)

Agent

Alicia

Russians
Adam Smith maintained that free enterprise is a mechanism that ensures the balance of society and sustains itself, talking about balance in an era when the concept of feedback had not yet been mentioned. When Nash said that a balancing formula could be postulated for dialectic situations such as competition and gambling, Nash was referencing Adam Smith.

During his second visit to the club, Nash formulates his balance theory by completing his mentor Morgensterns game theory with a matching scenario. This formula is to be published and then will make a great contribution to the science of economics, bringing a nobel prize to the author.

A symbol of the harshest example of dialectic situations, war, power and victory. This symbol is a source of John Nash's subconscious desire for power and plays an important role in his hallucinations.

A kind of initiation ceremony. John's value and talents are recognized by his peers. John's explanation to his mentor regarding the dissertation is synonymous with the set of fountain pens on an old mans desk.

This signifier may have a number of meanings: 1) the secret (every unknown that mathematicians and scientists seek to reveal are individual codes). 2) The talent John exercises, solving equations and matrixes that others are not able to understand with a single glance, makes him superior but also leads to his psychosis later on. 3) The emergence of the cold war two years after the end of World War 2, ignited the mystery syndrome all over the world. The interest shown in secret codes by the paranoid increased in this period.

This job, which was perfectly suited to John Nash's talents and character, became a main area of interest for him at MIT.

As John's pathology becomes more pronounced, the fear in the film becomes more apparent. 1) Doubt and fear are preliminary symptoms of paranoid disorders, 2) in this period the fear of nuclear war spread around the world.

The university in which Nash works on cracking the Pentagon password. Nash is a professor here (according to his biography, Nash worked at Stanford for a company names RAND, and was dismissed from his job).

Agent Parcher is a figment of John's hallucinations. Parcher is the manager of the Pentagon code breaker team and symbolises John's alter-ego. John fantasises about doing things he is not able to do through Parcher, adding even more power to the power he desires.

The character is a romantic aspect of the film for the audience. The degradation of John's personality is shown through his introduction to his wife, the proposal, the marriage and after.

The film does not portray any real Russians, However Nash's chosen antagonist/enemy is felt in all secrets and imagined threats. This signifier has two main objectives: 1) A target serving John's desire to be powerful, superior and victorious (hero of the national archetype), 2) A rational reason preparing the basis for the hallucinations. At that point the nuclear armament race between America and Russia became a serious threat. The entire world was anxiously watching and espionage was rampant. The Rosenberg case was widely reported. 
Adam Smith

Blonde girl exposure

Pentagon

Beer party in the garden thrown in John's honour after his dissertation proposal has been accepted

Codes (cyphers)

Code breaking

Fear

MIT (Massachussettes Institute of Technology)

Agent

Alicia

Russians
Adam Smith maintained that free enterprise is a mechanism that ensures the balance of society and sustains itself, talking about balance in an era when the concept of feedback had not yet been mentioned. When Nash said that a balancing formula could be postulated for dialectic situations such as competition and gambling, Nash was referencing Adam Smith.

During his second visit to the club, Nash formulates his balance theory by completing his mentor Morgensterns game theory with a matching scenario. This formula is to be published and then will make a great contribution to the science of economics, bringing a nobel prize to the author.

A symbol of the harshest example of dialectic situations, war, power and victory. This symbol is a source of John Nash's subconscious desire for power and plays an important role in his hallucinations.

A kind of initiation ceremony. John's value and talents are recognized by his peers. John's explanation to his mentor regarding the dissertation is synonymous with the set of fountain pens on an old mans desk.

This signifier may have a number of meanings: 1) the secret (every unknown that mathematicians and scientists seek to reveal are individual codes). 2) The talent John exercises, solving equations and matrixes that others are not able to understand with a single glance, makes him superior but also leads to his psychosis later on. 3) The emergence of the cold war two years after the end of World War 2, ignited the mystery syndrome all over the world. The interest shown in secret codes by the paranoid increased in this period.

This job, which was perfectly suited to John Nash's talents and character, became a main area of interest for him at MIT.

As John's pathology becomes more pronounced, the fear in the film becomes more apparent. 1) Doubt and fear are preliminary symptoms of paranoid disorders, 2) in this period the fear of nuclear war spread around the world.

The university in which Nash works on cracking the Pentagon password. Nash is a professor here (according to his biography, Nash worked at Stanford for a company names RAND, and was dismissed from his job).

Agent Parcher is a figment of John's hallucinations. Parcher is the manager of the Pentagon code breaker team and symbolises John's alter-ego. John fantasises about doing things he is not able to do through Parcher, adding even more power to the power he desires.

The character is a romantic aspect of the film for the audience. The degradation of John's personality is shown through his introduction to his wife, the proposal, the marriage and after.

The film does not portray any real Russians, However Nash's chosen antagonist/enemy is felt in all secrets and imagined threats. This signifier has two main objectives: 1) A target serving John's desire to be powerful, superior and victorious (hero of the national archetype), 2) A rational reason preparing the basis for the hallucinations. At that point the nuclear armament race between America and Russia became a serious threat. The entire world was anxiously watching and espionage was rampant. The Rosenberg case was widely reported. 
Secret information, codes, communication The necessary clichéd material based on reality but leading through newspaper articles

Template/archetype

His roommate Herman and the little girl to a spy story developing through hallucinations.

The image of the octopus and umbrella appearing in the night sky when John takes his fiancée to a party. This signifier alludes to John's ability to solve matrices at a glance and prepares the ground for his discovery of made up messages among newspaper cuttings.

Both characters form the content of severe hallucinations. Herman signifies two facts:

1) When John arrived at Princeton aged 19, his illness had already started to progress, 2) His schizoid character (introverted, unable to form relationships) created a need for friendship, which John fulfilled through his fantasies. The little girl would appear in later years to complete the fantasy.

Code breaking centre in an abandoned building, magnetic code number under the skin of John's arm

Driv by attach, chase and destruction of the enemy car

Doubting surrounding people

Panic reaction in class, desire to stop the imagined code breaking job, living at home in fear

Dr. Rosen

The severe seziures in hospital, cutting his wrist with a fingernail Insulin come treatment

After leaving hospital, the drugs prevent John from having sex and his wife has a fit

John forgets his baby in the bathtub

His wife finds newspaper cuttings in the garage

Return to Princeton and plea for help

Speech with the Dean and permission to enter the library.

John tells Parcher and Herman and his niece in his hallucinations that he will not speak with them any more

News regarding the Nobel Prize

Fountain pens on Nash's desk in the faculty hall

Nobel Prize ceremony

The continued hallucinations and crying girl
Hallucination material indicating John's duty to save the country against the powers represented by Agent Parcher.

Hallucination detailing living dangerously and beating the enemy.

1) An indication of paranoid mental illness, 2) and indicator of societal paranoia during the cold war.

A sign that the paranoid disorder has progressed.

This character is portrayed in the film as a sullen psychiatrist but is perceived by John as a KGB agent. This ambivalent attitude is held by John's wife and the audience. This aspect is used to increase tension in the film.

Indication of severe mental illness.

The most effective schizophrenia treatment of the era.

This indicator represents a true aspect of schizophrenia treatment.

An indication of the dangers of schizophrenia

The illness relapses after medication treatment ends.

The treatment allows John to regain his rationality and start to understand his limitations.

Emotions of value, love and understanding.

The dominance of complacency in schizophrenia and despite the hallucinations, the pathologies begin to recede.

A sign of unexpected happiness (also a message given to the viewer).

A symbol of appreciation, love, respect, celebration and elevation (this scene, repeated after 47 years, symbolises a deserved reward).

The zenith and happy ending

An image emphasising that it is important not to lose hope, even though the suffering has not ended. 


\section{A COMPARISON OF THE SIGNIFIERS (JOINT FINDINGS)}

The joint signifiers in both films are summarised as follows:

1. Mathematician: In both films the protagonist is emphasised to be a "mathematician" type youth, a young genious, researcher, with a desire to research and discover, not like ordinary people, fond of being alone, isolated to a degree from society, not caring about his daily appearance and clothing, showing awareness of the relationships behind appearances and challenging life to reach the absolute truths.

2. Mathematicians: The archetype to which the protagonists of both films adhere to is the mathematician, a signifier that points to all scientists. These people have extraordinary talents, are constantly judged by society and considered as eccentric or within a world of their own, constantly in competition and challenging all.

3. Mathematics: In the films, mathematics reflects the nature of reality and the laws of nature and is symbolised as the most superior and valid instrument to reach all secrets. A second function of mathematics as a signifier is to indicate modernity or modern technology.

4. Intelligence: The films show intelligence as the most superior product of human evolution and the mystical key to all knowledge. On one hand this is signified by mathematics and by computers on the other. This superior signifier is also reflected as the human mind and the human brain from time to time.

5. Schemes, numbers, codes and cyphers: In both films the concept of "secrets" are used frequently to indicate the unsolved mysteries of nature as well as a critical indicator within the fabric of the films.

6. The game of Go: This game represents a challenge based on intelligence in both films, and is a strong signifier of all dialectic situations such as was, gambling, commercial competition, economic conflict, diplomacy, politics and sport.

7. The student - teacher relationship: Both films use this signifier in terms of conflict, with both the positive and negative aspects indicating dichotomy in social relationships such as that between a father and son or clash of generations.

8. Teleology: This approach can be defined as attitudes and behaviour geared towards a certain goal and appears in both films signifying the protagonist's desires to know as well as the dialectic situations as mentioned above.

9. Fear: The fear described in Pi is apocalyptic, while that in a Beautiful Mind is related to nuclear war, both being realistic when considered in depth.

10. Protagonists and Antagonists: The conflict ridden and frightening dialectic situations described clearly in both films bear the genre mark of the conflict between friendly forces and enemy forces.

11. Tension: Internal tension reflecting on the signifier above is felt in every scene in the film.

12. Violence: There are a number of scenes in the films that depict violence, strengthening the feelings of tension.

13. Doubt: The paranoid state of the hero of a Beautiful Mind and the three latches on the door shown in Pi reflect doubt and the general anzieties of the age that we live in.

14. Paranoid fears and panic attacks: The films show more intense indicators of the anxiety and doubts listed above.

15. Hallucinations: During the epileptic seizures depicted in Pi and in the daily life of John Nash, the protagonist of a Beautiful Mind, hallucinations, as the indicator of an ongoing serious mental illness, are present in a number of scenes.

16. The burden of treatment: The difficulties of the treatment of schizophrenia and epilepsy are depicted openly in the films. The insulin shock therapy applied to John Nash and the torture of Max Cohen despite the fact that he takes handfuls of pills are depicted realistically.

17. Blood: Blood is always a severe and effective signifier. Blood indicates an attack on life whenever it appears. The scene where Nash's arm is torn is especially dramatic. Cohen's hallucinations seem to prepare the ground for suicide.

18. Guns: Instead of guns, signifiers with secondary meanings such as electric drills and vaccine guns are used as a signifier for attack in a Beautiful Mind and as a signifier for both attack and suicide in Pi.

19. Breakdown of the mind: This signifier has a deeper meaning in both films and brings a feeling of pessimism. The breakdown occurs with a drill in one and a severe mental illness in the other, transforming the messages of the films into open ended questions.

20. Definite solutions: Not present in either of the films. The signifier showing that the problems will continue is that of the little girl in the final scenes. 


\section{DISCUSSION AND CONCLUSION}

The age that we are living in is one of transformation. All of the gains of the era, both material and abstract, are the products of a socio-cultural phenomenon that were refer to as the "Age of Enlightenment". The Age of Enlightenment, that became fully formed and had completed its independent development by the middle of the 18th century, inherited its main principles from the Renaissance. "The most important aspect of the movement was the shift from dogma to observation and experimentation. The most significant gains of the Age of Enlightenment were technology and science. Other important results of the Enlightenment, the concept of human rights, democracy and an explosion of cuture, had elevated mankind to new hights" (Cevizci, 2000; Bozkurt, 2000). However, the teleological phenomenon (means to an end) and anxieties regarding life and happiness, effective on all living things, means that competition, conflict and even cruelty to the fellow man was to continue. The advancement of technology in leaps and bounds meant that solutions to dialectic situations (war, economic competition, gambling, war games etc.) were more horrific and bloody every time. "Within the last century we have seen two world wars, the ongoing threat of weapons of mass destruction, throwing the shadow of fear and doubt upon the consciousness of human beings.üşür. Civilizations and cultures are in a constant state of change. However, in the last 5 decades, the change has taken on the character of a crisis" (Bozkurt, 2000; Bolay; Cevizci, 2000). Some artists and philosophers consider this to be the end of an era or a historical crossroads. "Amittai Etzioni considers this new age to be the postmodern era, George Lichtheim describes it as the post-bourgeois society, Herman Kahn as the post-economic society, Murray Bookchin as the post-scarcity society, Kenneth Boulding as the post-civilised society, Daniel Bell, as the post-industrial society, Peter F. Drucker as the knowledge society, Paul Holmes as the personal service society, Ralph Dahrendorf as the service class society or post-capitalist society, Zbigniew Brzezinsky as the technocratic era and Y. Masuda as the information society olarak adlandırmışlardır" (Bozkurt, 2000). Consequently, the healthy offspring of the Enlightenment, modernity, has lost its old attractiveness. It would be beneficial to point out some phenomen on that are the indicators of the transformation of the age: Splitting of the atom, the space age, the beginning of the automation era, the computer being used to aug- ment human intelligence, the exponential increase of communication and knowledge dispersion, the complete change of the concept of war with the introduction of devastating weaponry, the downfall of sociocultural organizations (languages, institutions, maybe even states) the rapid degredation of the environment and the waste of raw materials.

Faced with these developments, the concepts of the Enlightenment and modernity and the creator and responsible party for all these developments, the human mind, are being perceived differently. What will the evolution of the products of the human mind bring? Is the light at the end of the Enlightenment tunnel scorching? This is the unknown fear.

The critical perspective aimed at the human mind is reflected in art and the film sector has emphasised the thought that the mind has become an "object of anxiety". The signifiers indicate a collective fear rampant in society in the era that the films were made. Here we mean the fear felt towards the products of the era. In Pi the anxiety regarding the conflict of interest in the society of the USA is being depicted while a Beautiful Mind contains various signifiers indicating the fears imprinted on the society of the cold war era.

The fear of the $3^{\text {rd }}$ World War affected social life in all aspects after 1945 and the events of 9/11 and the war on terror in recent years is a reflection of this fear. Indeed, the fact that a modernist vehicle used for transportation was transformed by the human mind into an instrument of terror on $9 / 11$ is a phenomenon that has been widely departed. However, the use of fear as a weapon has been a significant point when considering the modes of terrorism that utilise modern weapons of mass destruction. These fears, together with the birth of modernity, have been effective on every segment of society. In both films, the anxieties preceeding these fears are very apparent.

Furthermore, the tragic events that befall the protagonists in both films have a certain parallel. One of these is Nash's fate in his ideals while the other is Max Cohen's epileptic suicide. It would not be wrong to say that Max's lobotomy is in fact not "suicide". The suicide depicted here is probably intended as a metaphor: "if you do not think you will be comfortable and it will be less painful". In this way, the tension and even pathological status of the protagonists' personal tragedies are in a sense, validated for the entire society. In this age, humankind, with the tendency to feel anxiety towards rational thought and civilization as its product, is instrumentalising the developments of civilization in various forms. 
"Societal schizophrenia" is a post-modernity metaphor, indicating that people of the same society, same social organization or category are disagreeing and fighting amongst themselves."Seeking a secret intent under every stone, a secret meaning in every statement, is a severe symptom of mental illness that we classify as psychosis" (Işık, 2001). Moreover, the society or group in question displays a deep rift, conflict or inconsistency within its own personality, similar to a schizophrenic. This term may be just a metaphor, but societal divisions have been seen in history from time to time. It is controversial to describe these situations as psychotic, as adverserial ideas and actions may not be delusional. Indeed, theories explaining social dialectics, from Hegel to Marx, consider this situation as a normal societal phenomenon. However, we also see in history that the collective psychosis described here has been a reality. "Some historians, especially Royalists, describe the French Revolution as an age of terror or murder. The religious wars of the $16^{\text {th }}$ century, especially the 30 Years War mentioned by Eco, are seen by some as the mania of the West. Some sociologists have described the Red October in Russia and the phenomenon of Nazism in the same way" (Iş1k, 2001).

Looking at the millennium frenzy, we see that collective psychoses occurred in Europe in the run up to new years day in 1000 A.D. Similar cult psychoses occurred in 2000 (Vatandaş, 1999). The philosphers of the postmodern age, such as Virilio, Baudrillard and Foucault have made similar observations. This study does not make the claim that modernity is in a state of collective psychosis. However, the state of anxiety of the modern world is apparent in both films. In a Beautiful Mind, the period in which John Nash is living is the era of McCarthyism in the USA (Feber, 1997). The play (witches cauldron), inspired by the Salem Witchcraft Trials and the Name of the Rose, is set in a period in which the intellectuals and universities in the USA were "under the effects of collective psychosis". "Walter La Feber's 'America, Russia and The Cold War' openly displays the reflections on academic circles" (Feber, 1997).

"Umberto Eco, announced this situation as a "Mystery Syndrome" despite having opposed this with an intense campaign throughout the 1980's" (Eco, 1996). According to Eco, this pathological approach was imprinted on every aspect of social life, affecting his belief system profoundly. The basis of this syndrome was a strong trend observed in the approach to events and statements, especially appearing in commentar- ies. This was the search for secret meanings and placing a weighted importance beyond appearances upon these meanings. In the war against the mystery syndrome, Eco published his first manifesto in his book "The Limits of Commentaries" in 1990. Later on, in his popular novel entitled "The Foucalt Pendulum", using a more sarcastic approach, he wrote about a "universal and historical conspiracy", focusing on a detective story in which three moden intellectuals, referred to as "the three magicians apprentices" by M. Caesar take the lead roles. As a semiotics expert and a medieval historian, Eco gave the mystery syndrome a historical background in "The Name of the Rose" and "The Foucault Pendulum" 6*.

"The eradication of the principle of consistency, one of the basic pillars of logic, leads to the downfall of rationality and the unrivalled domination of mysterious thought upon thought processes. This situation leads to pathologies seen in mental illnesses (Işık, 2001). In tense social periods (periods in which the change of the era brings the unknown to the forefront), the moderately pathological attitude Eco names the "mystery syndrome" becomes more widespread and we can conclude that real mental illnesses arise. The period in which a Beautiful Mind is set, is the cold war, that lasted from Churchill's famous speech made in the USA "the iron curtain has fallen"; ending with the fall of the Berlin Wall. The significant reasons why this period is considered as a transitional one between eras are listed below:

"The first atomic bomb and the advent of the nuclear age

The production of the Leniac computer and the first transistors and integrated circuits, leading to the information age

\footnotetext{
${ }^{*}$ In both novels there is tension between the protagonist and antagonist. In the same way, the doppleganger, reds and pentagon, us and them dichotomies are examples of this type of conflict. In the firs novel, the conflict is between the papacy and the emperor supporting secularism. The second novel describes the tension between the supporters of positive science and technology and the supporters of hermetic thought. According to Eco, hermetic thought is a psychological tendency that leads to mystery syndrome. This tendency discounts the principle of consistency in basic logic. According to this principle, it is not possible for something to exist and not exist at the same time. However, according to hermetic thought, everything is in a constant state of change and hermeticism has adopted the principle of universal sympathy and similarity. This principle states that everything is interconnected and mysterious relationships exist between phenomenon.
} 
The spread of the radio, television and cinema, designed as media of propaganda in the war years, the development of the media and the start of the communication age

The gigantic dimensions of Fordist-Tailorist mass production due to war, the use of feedback circuits to automate production and the start of the automation ate.

The journey of humans into Earth orbit and then to the moon, the revolution of interplanetary research vehicles." (Bozkurt, 2000).

In addition to the above, the exponential and unexpected development of science, technology, biology and medicine has made this short period a real crossroads of eras.

Both films focus on "transitional syndrome" as a collective problem. Especially a Beautiful Mind should not be read as the biography of a sufferer of mental illness, as the issues faced are collective rather than personal. If we think of postmodernism as an illegitimate child of modernity, we can say that the tensions in both films are of the same cause at the basic level. In conclusion, the anxieties perceived in the films are reflected using basic statements, as summarised below:

1. The mind is a dangerous instrument. Men should not keep looking at the sun. Thinking, learning and knowing too much is dangerous! This statement is one of obscurantism, which had been dominant for centuries in the West.

2. The mind is limited, while the truth is transcendental. The truth is not only unknown, but unknowable. The enlightenment, a product of rationality, is useless. The real enlightenment is illumination. Illumination is the will of god. This mysticism continues to exist today in various sects and cults, within metaphysical systems.

3 . The mind is the most valuable instrument, but evil has not be prevented. Too much pessimism leads to the downfall of the mind. The mind may also be a solution to the problems it creates. The name Nobel has a certain charm to it. Nobel discovered dynamite, ending the lives of many, but the prize offered with the income from this invention prevents many diseases and solves problems of poverty.

The little girl seen in the final scenes of both films is an important signifier. "This is not over, it will go on".

\section{REFERENCES}

Arslanoğlu, K. Akman, M. B. (2002). Psikiyatri El Kitabl, İstanbul: Adam Yayınları.

Barthes, R. (1966). Rethoric of the Image

Bolay, S. H. (1997). Felsefi Doktrinler ve Terimler Sözlüğü. Ankara: Akçă̆ Yayınları

Bozkurt, V. (2000). Enformasyon Toplumu ve Türkiye. İstanbul: Sistem Yayıncılik.

Caesar, M. (1999). Umberto Eco, Philosophy, Semiotics and the Work of Fiction. Cambridge: UK Polity Press.

Cevizci, A. (2000). Paradigma Felsefe Terimleri Sözlüğü. İstanbul: Paradigma Yayınlar1.

Cüceloğlu, D. (1991). Insan ve Davranışı. İstanbul: Remzi Kitabevi.

Eco, U. (1993). Foucault Sarkacı (Çev. Ş. Karadeniz). İstanbul: Can Yayınları.

Eco, U. (1996). Yorum Aşırı Yorum. İstanbul: Can Yayınları.

Feber, L. W. (1997). America Russia and the Cold War 19451996. The McGraw-Hill Companies, Inc.

Işı, E. (1997). Şizofreni. Ankara: Kent Matbaacılık.

Işık, E. (ed). (1999). Organik Psikiyatri. İstanbul: Tayf Matbaası. Işık, E. (2001). Gazi Üniversitesi Tıp Fakültesi, Psikiyatri Anabilim Dalı Başkanı. Kişisel Görüşme. Ankara.

Krech, D. Crutchfield, R. S., William, A. W. JR. (1974). Elements of Psychology. Alfred A. Knopf. Inc.

Morgan, C. T. (1991). Psikolojiye Giriş (Çev. Arıcı, H. Ve ark. Ed. Karakaş, S.). Ankara: Meteksan Ltd. Şti.

Rifat, M. (2000). XX. Yüzyılda Dilbilim ve Göstergebilim Kuramlarl, 1. Tarihçe ve Eleştirel Düşünceler. İstanbul: Om Yayınevi.

Rifat, M. (2000). XX. Yüzyllda Dilbilim ve Göstergebilim Kuramlarl, 2. Temel Metinler. İstanbul: Om Yayınevi.

Stahl, S. A Gentle Introduction to Game Theory. 